\title{
Planning the Dewatering of a Tailings Storage Facility
}

\author{
Eduardo Ruiz ${ }^{1}\left(\right.$ Lizardo Huamaní $^{1} \cdot$ Jairo Paucar $^{1} \cdot$ Julio Larota $^{1} \cdot$ Carlos Jiménez $^{2} \cdot$ Yuri Gallo $^{2}$
}

Received: 6 April 2020 / Accepted: 24 November 2020 / Published online: 5 January 2021

(c) The Author(s) 2021

\begin{abstract}
The San Rafael mine in southern Peru produces over $10 \%$ of the world's tin. The decision was made to reprocess some of its oldest tailings, due to their volume and high tin concentrations. This tailing storage facility was partially saturated and required a dewatering process to allow mining. This paper describes the conducted activities for this dewatering, including basic engineering studies focused on hydrogeological characterization of the tailings, recommended tests and modelling to define a detailed engineering design, and developing an appropriate construction strategy. In addition, there were tasks associated with operating the dewatering system, infrastructure maintenance, and a real-time follow-up implementation program to monitor the desaturation. The system's historical evolution, a year of dewatering, and the beginning of mining activities are reviewed.
\end{abstract}

Keywords Pumping wells $\cdot$ Non-saturated parameters $\cdot$ Modelling scenarios $\cdot$ Water management $\cdot$ Dewatering system . Water content

\section{Introduction and Motivation}

The mining industry produces several thousand million tonnes of waste a year, which the same order of magnitude as that of fundamental Earth-shaping geological processes (Förstner 1999; Fyfe 1981). Part of this volume is frequently placed in tailings storage facilities (TSFs), which can fail if there is not an adequate design to ensure physical stability (Kossoff et al. 2014). The potential causes of failure are diverse, depending on whether the TSF is active or not (Rico et al. 2008), the stage in which the deposit fits in the life of mine (i.e. construction, operation, or closure), and various intrinsic factors (e.g. tailings granulometry (particle size distribution), hydraulic conductivity, consolidation, and infiltration); and extrinsic factors (e.g. the geology of the bedrock, precipitation, disposal and operation of new tailings, water drainage, and seismic events).

For decades, we have witnessed numerous economic and environmental disasters. Examples include the collapse of the TSF in Aznalcóllar mine (Spain) in April 1998 (Eriksson

Eduardo Ruiz

eduard.ruiz@amphos21.com

1 Amphos 21 Consulting Peru, Jr. Pietro Torrigiano 396, San Borja, Lima 41, Peru

2 Minsur, Jr. Lorenzo Bernini 149, San Borja, Lima 41, Peru and Adamek 2000) and more recent disasters associated with stability failures, such as the recent rupture of the Brumadinho TSF (Brazil) in January 2019.

The mining community must proactively isolate the tailings from groundwater, rivers, and lakes (Kossoff et al. 2014), considering that water is a key factor in terms of impacts on the environment and the physical stability of the facility. For example, the groundwater and capillary water stored in the unsaturated zone of the tailings ponds or dams are variables that can directly influence the safety and physical stability of these facilities (Lambe and Whitman 1969). Therefore, monitoring water levels and moisture evolution within the tailings over time provide fundamental parameters for both design and safety control. Water inside the dikes and slopes of tailings significantly influences the stability of these structures, reducing their safety factor, especially in seismic risk areas where processes such as liquefaction play a relevant role (Olson and Stark 2003; Youd and Idris 2001). The latest industry trends are moving towards TSF designs with the least amount of water possible; hence, technologies like filtered tailings or dry stacking are growing internationally.

Among control methods to enhance the physical stability of TSFs, groundwater dewatering has been efficiently used in large underground engineering (Huang et al. 2018), and can be used to recover the potential economic value 
from saturated ancient tailings. Likewise, in arid regions for which the balance between precipitation and evaporation is highly deficient, dewatering a TSF can be a source of water that can partially cover the demands and requirements of the mining process.

This article will address key aspects to be considered when dewatering is planned and is based on The authors' experiences during the dewatering of an old TSF associated with Minsur's San Rafael mine in Peru. This dewatering process had two objectives: (1) enhancing the physical stability of the embankment sector, and (2) reprocessing the old tailings, which had economic (ore grade) value. However, dewatering tailings can be a titanic task, since the low permeability of tailing materials makes this an engineering challenge.

\section{Site Description}

San Rafael is an underground mine that exploits an unusually high grade, lode-type $\mathrm{Sn}-\mathrm{Cu}$ deposit in the Eastern Cordillera of the Peruvian Central Andes at an altitude between 4500 and $5000 \mathrm{~m}$ above level of sea (Fig. 1). As the leading tin-producing mine in South America and the fourth largest in the world, this mine produces over $10 \%$ of the world tin (Carlin 2005; Minsur unpubl. data 2000; Mlynarczyk et al. 2003).

The San Rafael mine lies within the Cordillera Carabaya, which is mainly a thick sequence of marine sedimentary rocks. Throughout the Phanerozoic, this region underwent convergent plate interaction, orogeny, and intermittent, mixed, mantle- and crust-derived bimodal magmatism (Clark et al. 1990).

As part of the productive strategy, San Rafael mine planned a project to reprocess some of the site's oldest tailings, located in a TSF named B2 (Fig. 1). The complexity of the site places this deposit next to (downstream of) the current tailings disposal deposit (B3), which will continue operating while the old tailings are excavated.

The geological context of the project is shown in Fig. 2; the B2 tailings deposit lies atop quaternary materials of glacial context (moraine), and intrusive materials (e.g. monzogranite) and metamorphic materials (hornfels, shales, and quartzites) exist upgradient.

In addition, upstream there is a lagoon (Chogñacota L.) that compels surface water overflow to be managed in the rainy season. The groundwater flow towards the B2 deposit can be considered low $(<2 \mathrm{~L} / \mathrm{s})$ appearing as diffuse infiltration in the northern part. A schematic understanding on how groundwater flow occurs in the B2 TSF is presented in Fig. 2.

The engineering was initiated in 2014 and developed from prefeasibility to detailed engineering in 2018, including environmental permits. Construction was initiated in 2018, so that remaining of the old tailings could begin by the end of 2019 , coordinated with operation of a new processing plant.

\section{Relevant Basic Studies}

In this article, we have focussed on the key activities that we consider relevant to planning and developing a dewatering strategy in a TSF. Extensive detailing of the methodological aspects and site-specific technical matters would require a broader report. Other aspects to consider will be mentioned in case the reader is involved in planning a similar project, from basic studies in engineering and implementation through to operation.

\section{Tailings Granulometry, Variability and Geometry of the Deposit}

The starting point when planning a dewatering system is to adequately characterize the TSF and the environment in which it is located. It is important to have a strategy to identify sectors with different physical properties and hydraulic conductivities: understanding of unsaturated parameters, porosity, and granulometry are essential (how they vary spatially and at depth, so that the heterogeneity is understood).

A block model was developed of the B2 TSF, which provided an accurate geometry of the deposit and knowledge about the contacts between the tailings, geological formations, and the environment (Fig. 3). Several laboratory tests were carried out from soil samples obtained by boreholes to establish the physical properties. As an example, granulometry curves were developed to identify areas of finer and coarser tailings.

Drilling campaigns should be as integrated as possible. Ideally, each borehole can provide geological-geotechnical information, data about the resources that allow a block model to be generated, details on the tailings' geochemistry and rheology, as well as the hydrogeological and hydrochemical information needed for conceptual models.

Diamond core drilling machines and resistivity/conductivity cone penetration tests (RCPTu) were used to sample the B2 TSF. Additionally, in order to acquire information on hydraulic parameters during the prefeasibility and feasibility studies, water wells were drilled to facilitate pumping and interference tests. The complete drilling campaign involved 96 geological/metallurgical boreholes, over 30 geotechnical and hydrogeological (piezometers) drillholes, and 25 production wells.

Integration of these site investigations allowed us to develop the conceptual understanding of, for example, the geotechnical implications of the planned excavation (see 

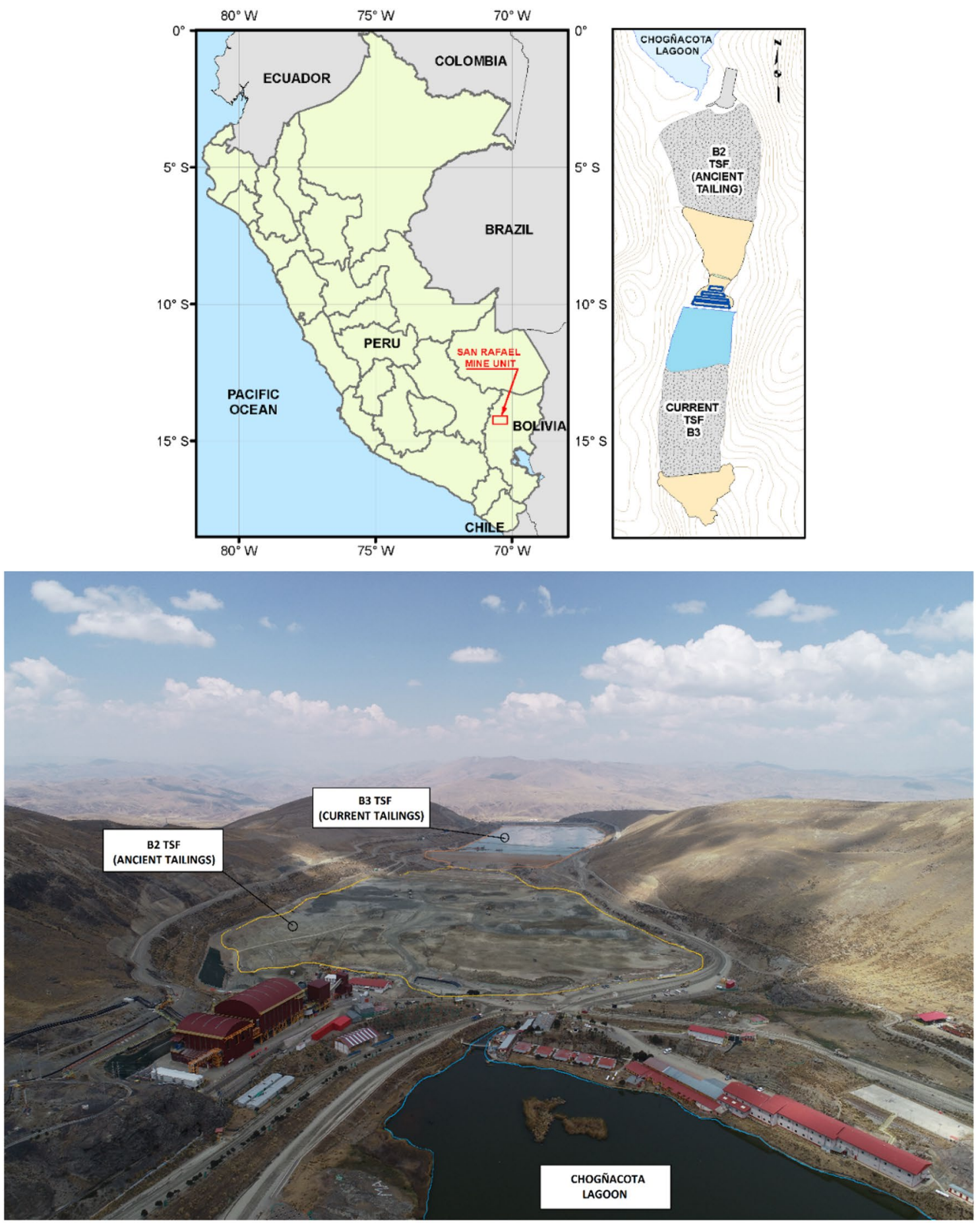

Photo courtesy Carlos Jiménez

Fig. 1 Location of the San Rafael mine (Peru), and below it, a general view of the B2 TSF (the tailings to be reprocessed) and B3 TSF, the current tailings disposal facility

an example in Fig. 4). From this, different hydrogeological units could be correlated, depending on their parameters.

\section{Hydrogeological Characterization of the Tailings}

TSFs usually present great spatial and depth variability in hydraulic conductivity and it is critical to understand this 

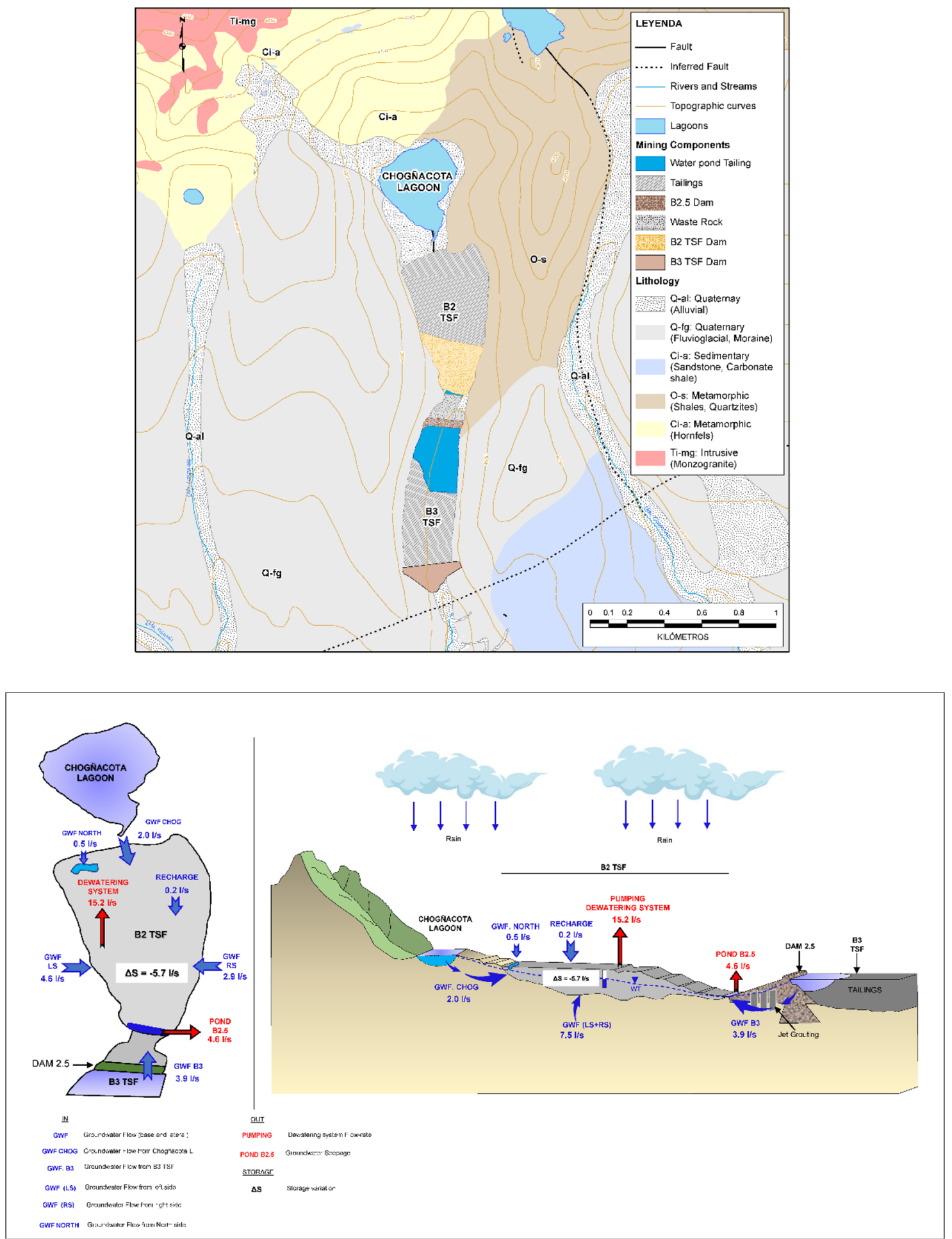

Fig. 2 Geological framework of B2 TSF, and below it, a conceptual/schematic groundwater balance in the B2 TSF

hydraulic behaviour. Often, a lagoon is formed from an embankment, according to the tailing's disposal plan. In these cases, it is very common that the tailings with finer granulometries settle furthest from the embankment.
Sampling, along with laboratory and field testing, was conducted to characterize the hydraulic behaviour of the tailings, and a wide network of piezometers was installed. A recommended lab test involved estimating retention (the 


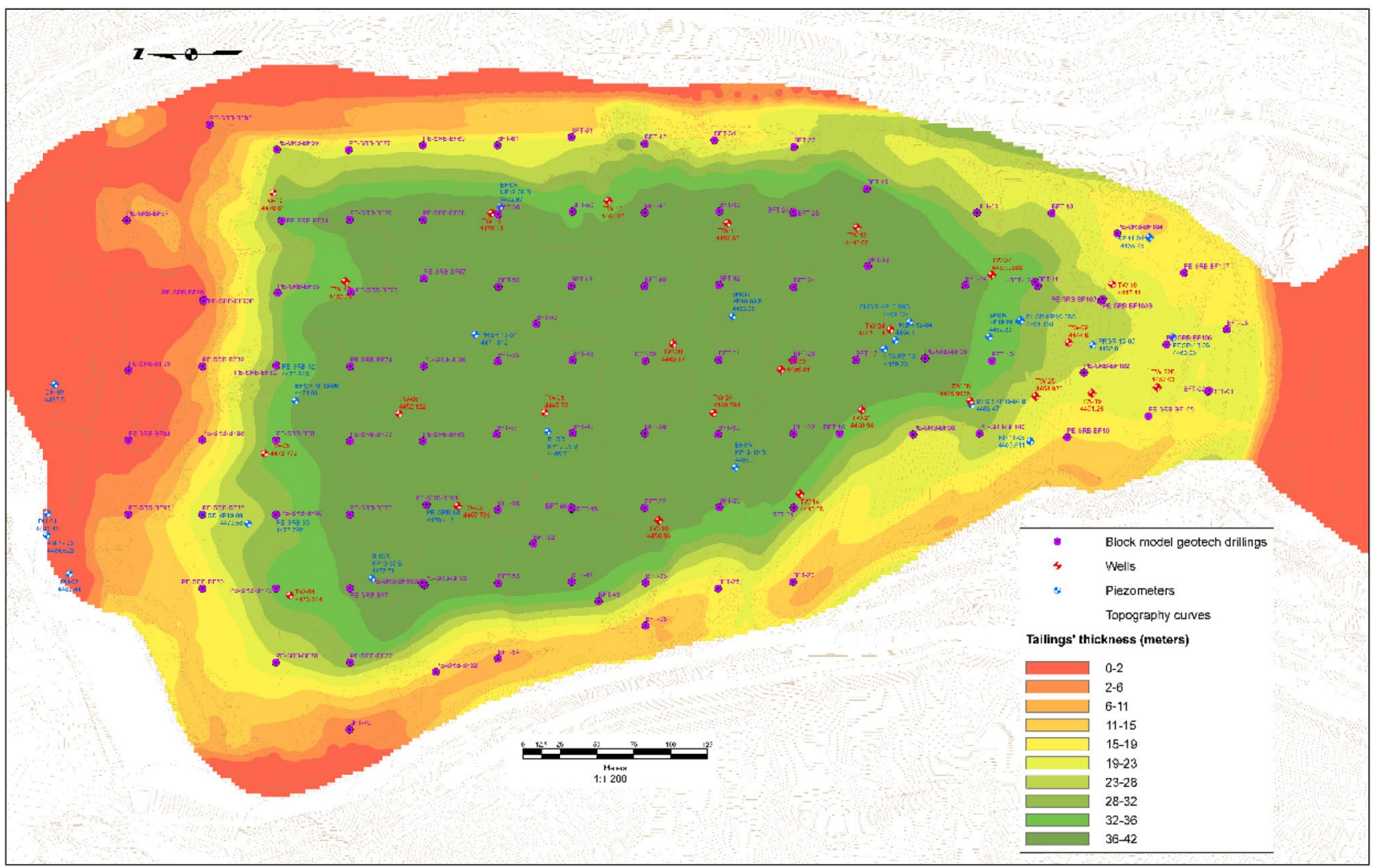

Fig. 3 Development of a block model of the tailings deposit: drilling campaign to generate metallurgical, geochemical, geologic-geotechnical, and hydraulic data (courtesy of Minsur)

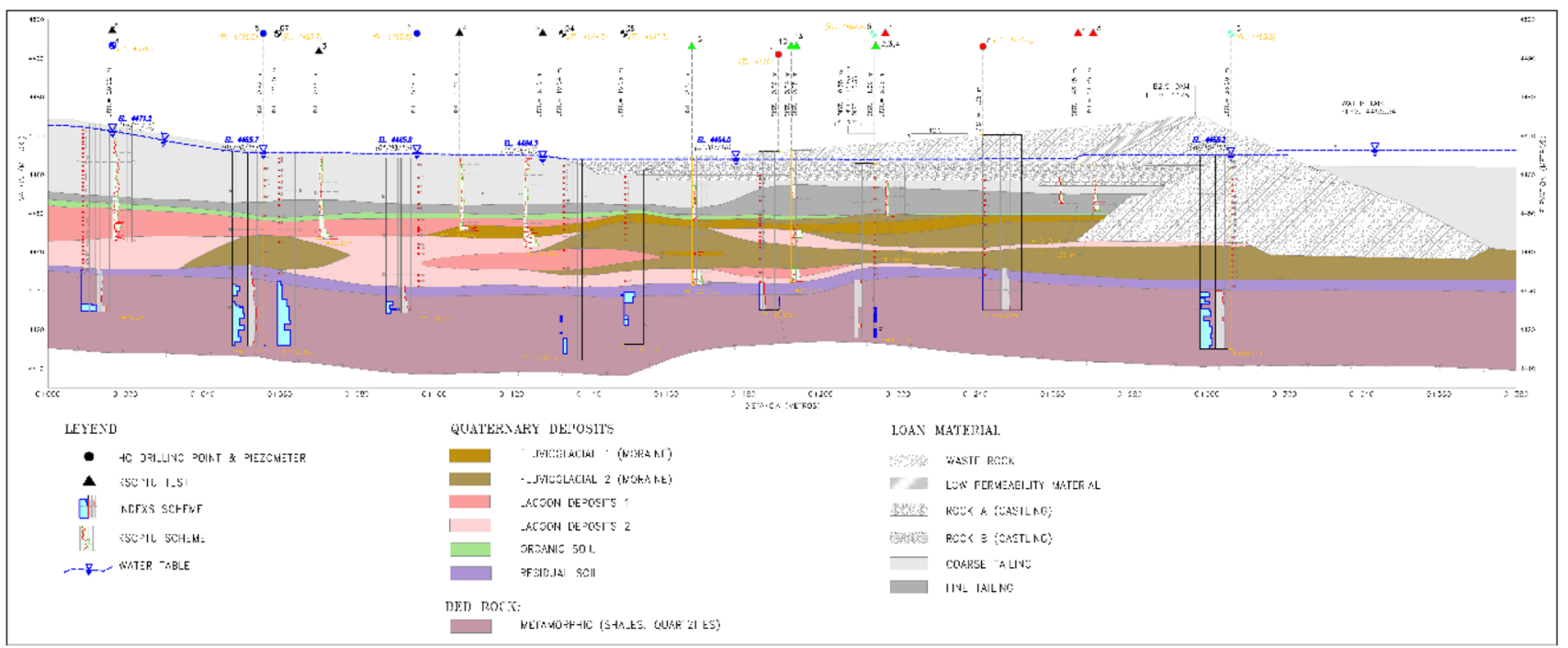

Fig. 4 Example of a geological-geotechnical cross-section of the embankment sector of the B2 TSF based on site investigation campaigns (courtesy Minsur) 
Fig. 5 Examples of typical curves for suction and their relationship to volumetric moisture content for different tailings samples (courtesy of Minsur)

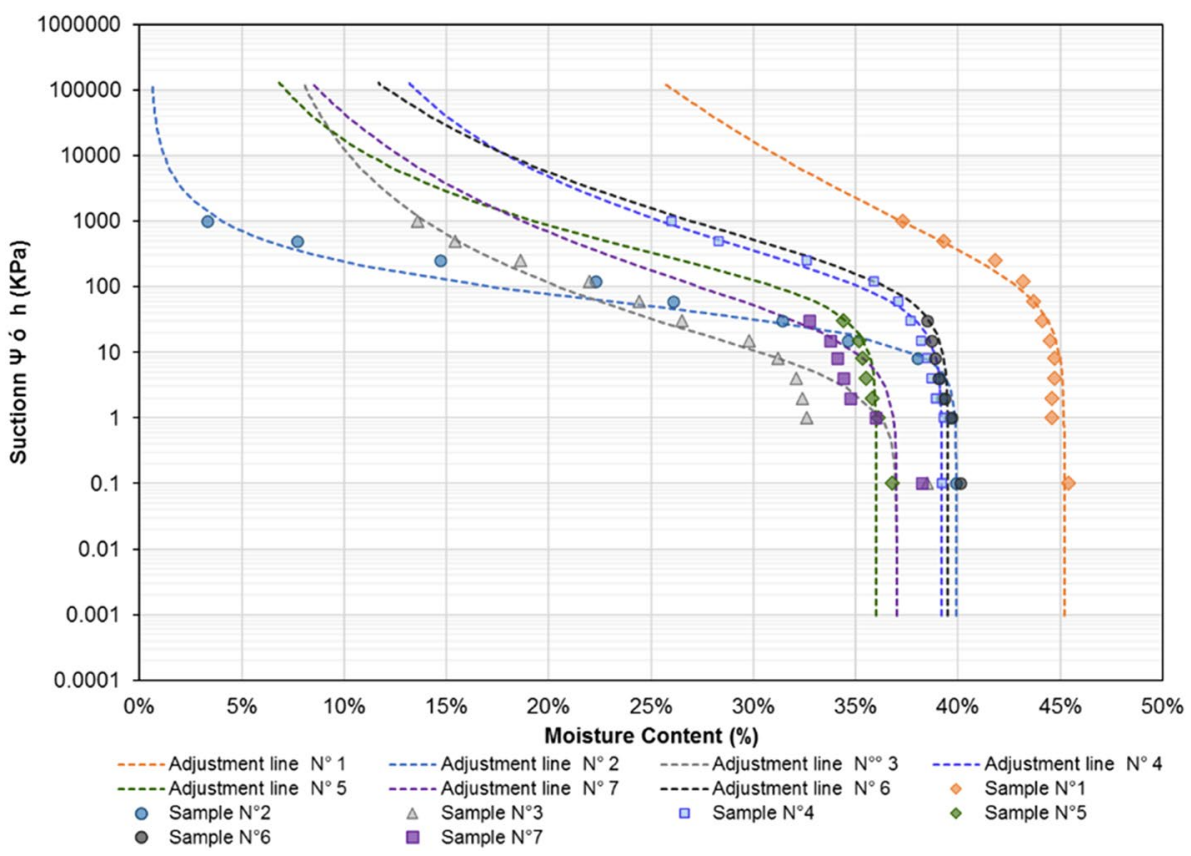

relationship between soil water content and suction; see Fig. 5).

These curves, variable depending on the granulometric nature of each layer of tailings, allowed us to estimate the porosity and associated hydraulic behaviour of the unsaturated zone. These must be explicitly incorporated in the hydrogeological modelling of the deposit and are key to estimating the degrees of saturation and/or water content after desaturation. They can also be used to help estimate the anticipated time to achieve maximum drainage.

To determine the hydraulic properties (saturated hydraulic conductivity and storage coefficient) of the tailings, hydraulic tests were carried out during the different phases of well drilling (Lugeon and Lefranc tests). Later, pumping and interference tests were carried out using the wells and piezometers installed in the area (Fig. 6). Despite the complex heterogeneity and stratification in the TSF, and important vertical and horizontal changes in permeabilities, hydraulic connections were assumed based on the drawdowns in the monitored piezometers.

The pumping tests and piezometers were interpreted using AQTESOLV software (HydroSOLVE Inc. 2008), and different widely-used analytical solutions (Papadopulos and Cooper 1967; Theis 1935). Hydraulic conductivities
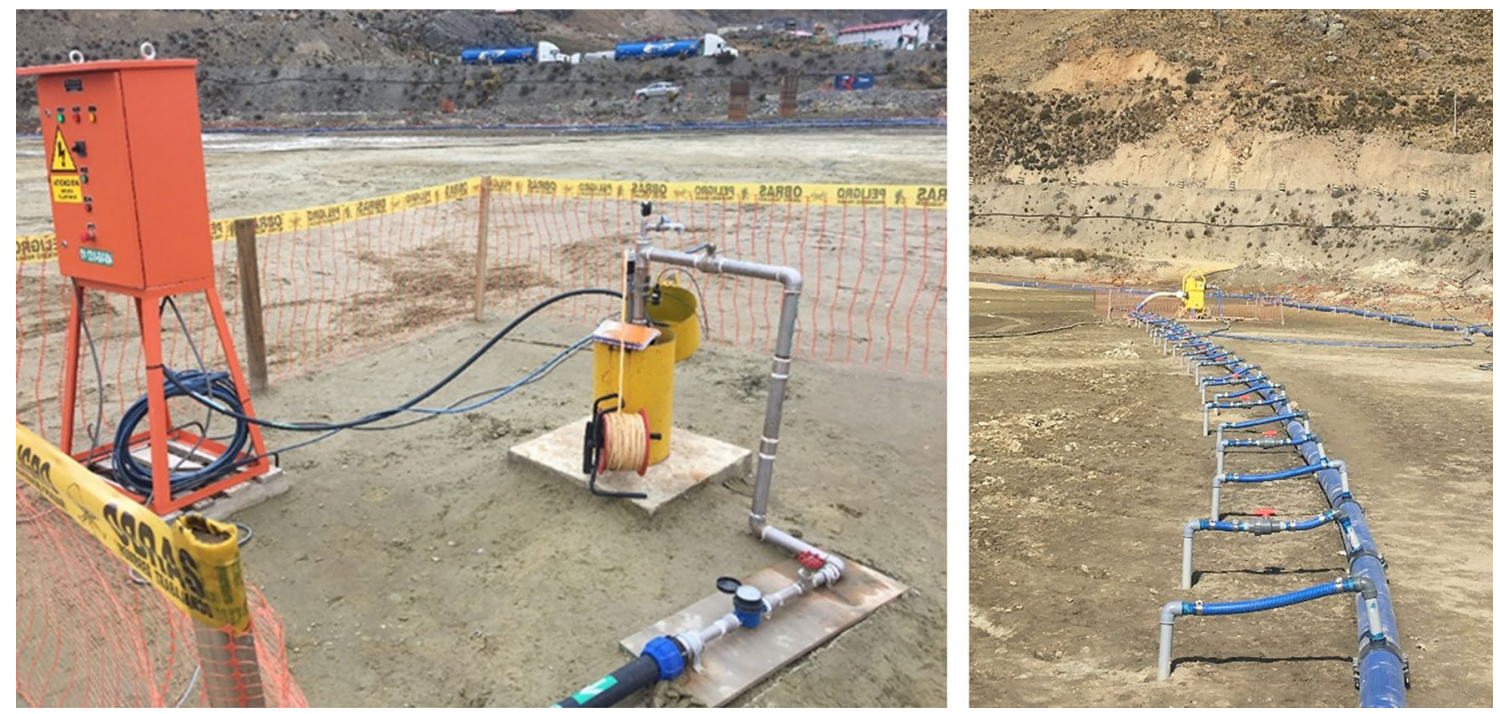

Fig. 6 A pumping well (left) and a wellpoint line (right) in the B2 TSF (Courtesy Julio Larota) 
(permeability) obtained from over 75 hydraulic tests conducted during the engineering stages produced estimates ranging from 1 to $0.05 \mathrm{~m} /$ day for coarse tailings; $0.05-0.0005 \mathrm{~m} /$ day for fine tailings; $2-0.05 \mathrm{~m} /$ day for the quaternary materials; and $0.8-0.0001 \mathrm{~m} /$ day for the metamorphic and intrusive host rock.

Wellpoint dewatering lines were incorporated into the design of the drainage system as a complementary methodology for sectors of limited thickness to allow us to intercept the natural (or regional) flow (Fig. 6). Its applicability in the context of low permeability materials was adequately tested in the design and conceptualization stages of the project to ensure its operability (pumping dimensions, filtered zones on lances, length lines, operation times, etc.). The results of these tests allowed us to understand the hydrodynamic behaviour of the TSF and define the most suitable dewatering system in the different sectors of the deposit.

\section{Conceptualization of the Dewatering Plan}

The hydrodynamic performance of the tailings was defined during the different engineering stages using the results of the different tests and the information collected and analysed (geology, evolution of groundwater levels, recharge and discharge of the system, surface runoff, hydrochemical and geochemical characteristics, etc.). Numerical modelling of the site during the reprocessing engineering studies allowed us to simulate and analyse different dewatering scenarios, varying the number of wells and locations, times and rates of pumping, as well as sectors and levels with different physical and hydraulic properties, according to the mine plan.

There are numerous commercial and research-developed software that allow the development of unsaturated flow models. Singularities of non-linear models are not part of this paper, considering that literature exists describing the phenomena and numerical approaches (Kool et al. 1987; Zhai and Rahardjo 2012). We used the FEFLOW code to undertake numerical scenarios in the definition of a dewatering system (Diersch 2005; see Fig. 7).

Modelling results established the need to implement 25 pumping wells, of different diameters ( 6 to 8 inches, or $\approx$ $15-20 \mathrm{~cm})$ and depths $(30-60 \mathrm{~m})$ conveniently distributed around the TSF. The wells were equipped with submersible pumps and the water was discharged by PVC pipes according to the dewatering management strategy (Fig. 8).

According to the hydrogeological model, the time required to dewater the entire area depended on the permeability of the tailings' sectors. Assuming that surface water input was properly managed to avoid recharging the TSF, about 8 months would be needed to dewater the central sector (the most permeable sector, formed mainly with sandand silt-sized particles) and about 18 months for the sectors with less-permeable fine materials (the northernmost and SE sectors, which had been determined to be silt- and claysized particles).

In addition, in the northern and southern (embankment) sectors, a wellpoint drainage system, consisting of lances or filter tips (5-6 m long, $2 \mathrm{~m}$ apart) was placed in the TSF around the area to be drained, and joined by means of

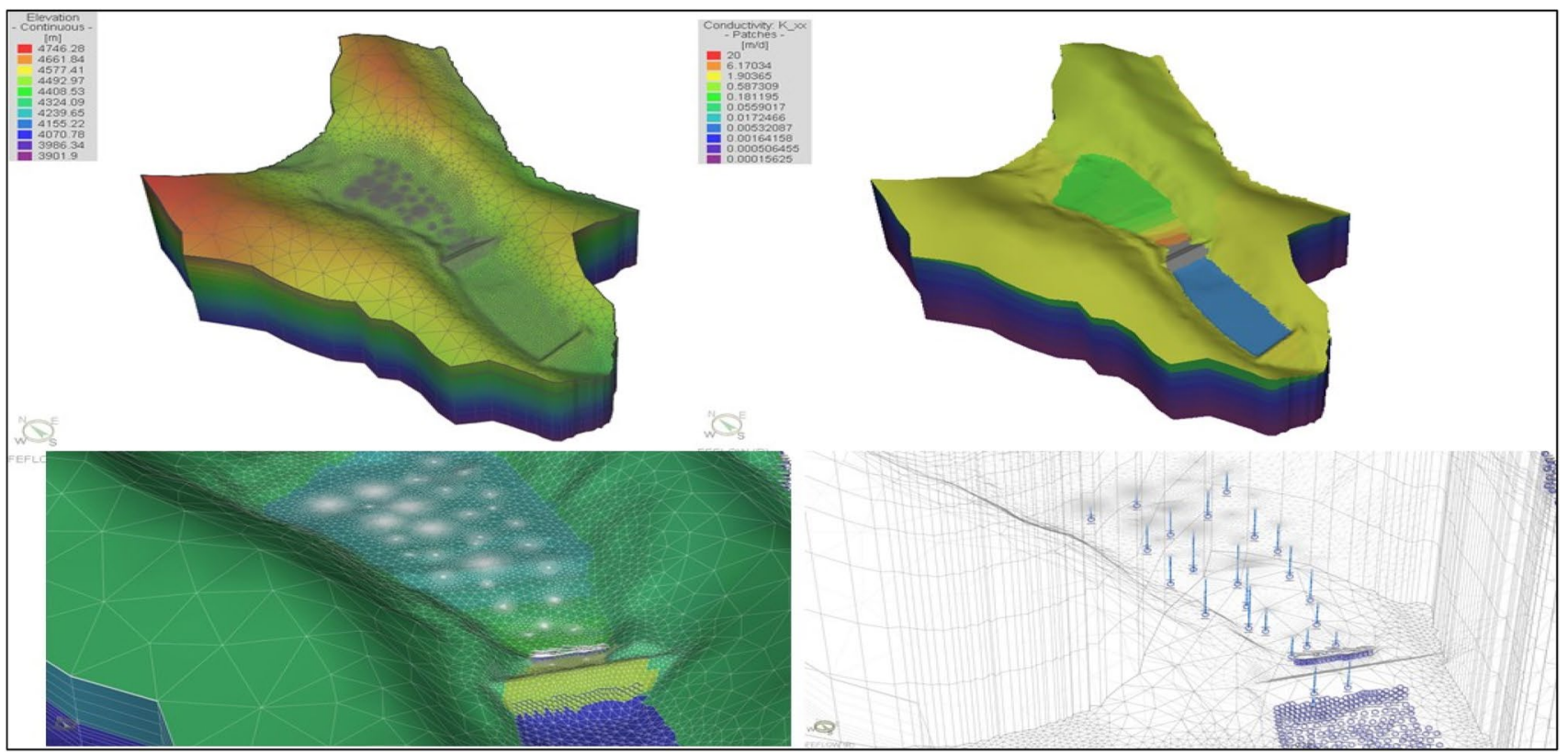

Fig. 7 Overview of the numerical model developed to support engineering of the dewatering system 


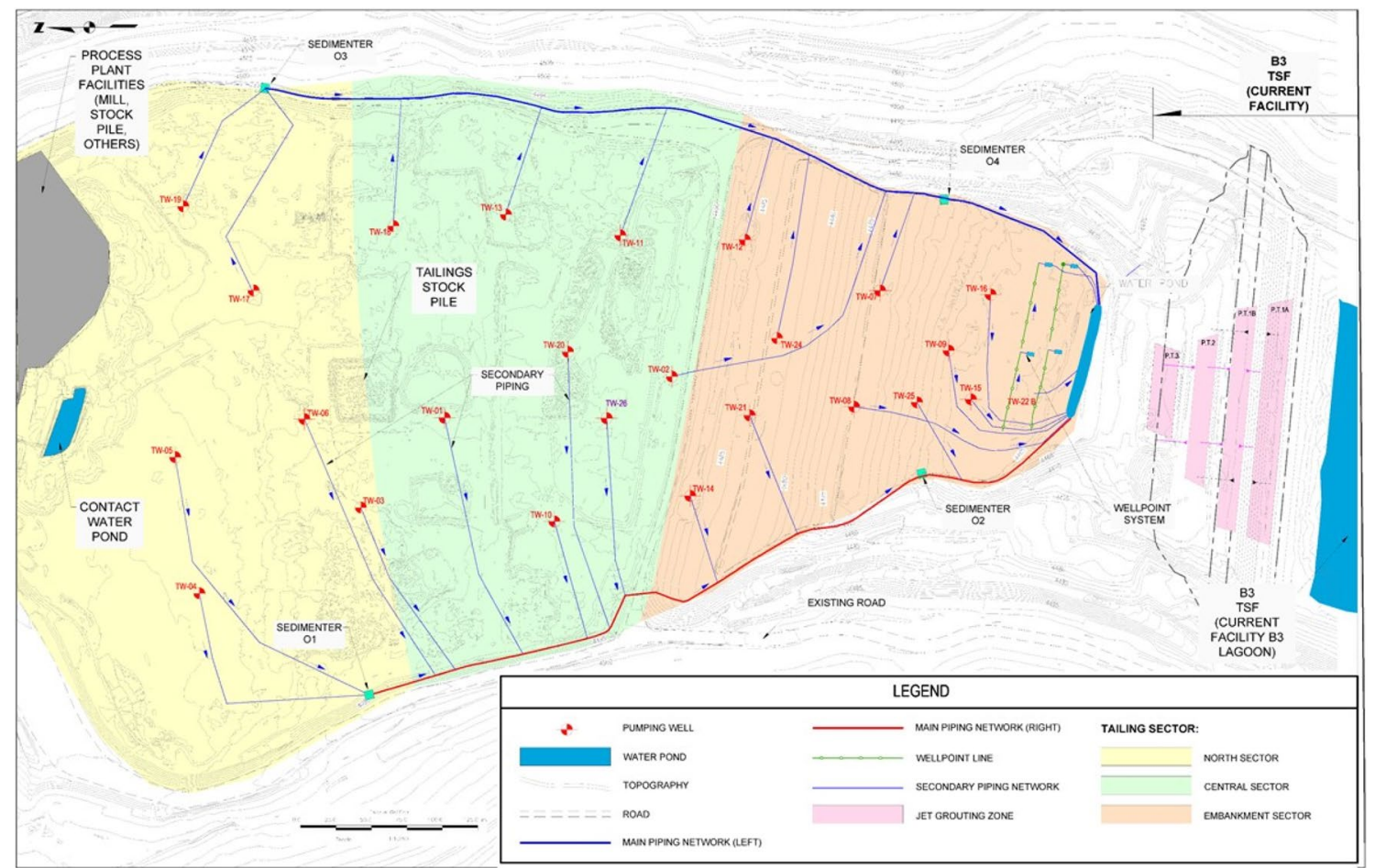

Fig. 8 Overview of the dewatering system-B2 (plan view)

corrugated coupling hoses to a perimeter collector, to characterize the hydraulic behaviour of the tailings. The dynamic nature of wellpoint systems allows them to be installed in and moved to different areas as mining progresses (Fig. 6).

\section{Key Activities During Implementation, Performance, and Monitoring}

The wells were developed in early 2018. The plan was to operate the wells, as needed, during the 9 years of material extraction. The system was designed to operate at a target level to ensure that there would be no future problems with the excavation and mining of the tailings.

Continued monitoring of the wells and piezometers allows the mine to analyse the evolution of the water levels and the drawdown by sectors (see Figs. 9, 10), and additionally allows them to adjust the pumping flow in each well to make it as efficient as possible and prevent equipment failures. Continued hydrogeological monitoring of the operation, combined with daily preventive maintenance of all equipment, will be needed to assure the operation of the dewatering system and verify that all of objectives are achieved in a timely manner.
Hydrogeologists should be part of the field team to integrate the information, and analyse the progress and performance of the system, along with electromechanical technicians to guarantee the operation of the equipment. Daily data gathering allows the evolution of water levels and drawdowns by sector to be assessed (Figs. 10, 11), to adjust the most efficient pumping flow in each well and to be periodically incorporated into the existing numerical model(s). The modellers can then, in turn, provide updated estimates and drawdown forecasts by sectors, allowing the mine to anticipate any potential deviation from the original plan.

\section{Reduction of Influent Water}

Water management in mining operations is often a highly complex activity and is key to avoiding unnecessary entry of water into the TSF system. Channels to divert rainwater run-on away from the TSF need to be engineered according to climatic conditions, considering risks associated with different seasons (see Fig. 12). Failure to divert such water negatively affects dewatering and complicates (delays) hydraulic drawdown. 


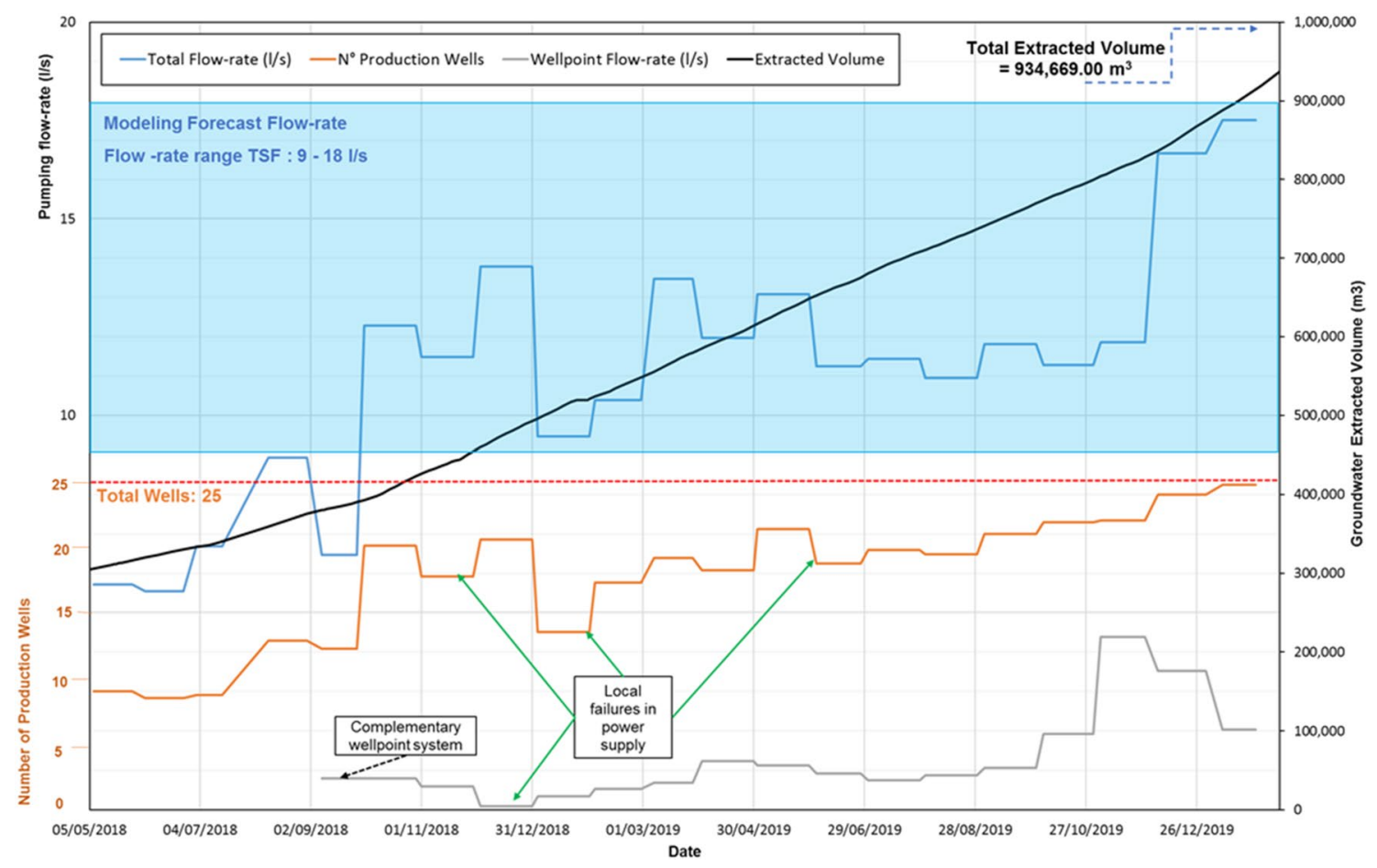

Fig. 9 Dewatering system performance. The necessary elements are number of operating (dewatering) wells, flowrates (individuals and global), failure control, wellpoint complementary systems

Wellpoint drainage systems can help lower water levels and reduce lateral recharge in sectors with a high content of silt- and clay-sized particles and relatively shallow water levels. Wellpoint distances need to be properly defined to work with these low-permeability materials.

\section{Hydrochemical Implications of Equipment Maintenance}

As expected by the TSF's hydrogeochemistry, the water is acidic $(\mathrm{pH} \approx 4)$ with high concentrations of sulfate, arsenic, manganese, and iron. This causes corrosion and clogging problems in the pumping equipment, pumps, and pipes (Fig. 13), which reduces the drainage system's efficiency. Thus, preventive maintenance of the water drainage and wellpoint systems, and particularly the pumps, valves, pipes, and instrumentation (measurement sensors), is important. Also, the effluent needs to be properly managed to avoid environmental impacts.

\section{In Situ Humidity Measurements and Tailings' Stockpiling to Ensure Dry Conditions}

During the excavations, trenches should be used to assess the area's capability of bearing the weight of heavy vehicles. Excavation of test pits, and sampling and analysis of the material's actual humidity, are of great value (Fig. 14). Drying the extracted material (water content linked to material porosity) is recommended to reduce the residual moisture content prior to processing. Some space should be reserved for this. These practices have already been conveniently implemented during the remaining of the B2 TSF (Fig. 15).

As previously mentioned, RCPTu were used during the project's site characterization stage. These types of tests provide an understanding of the pore pressure profiles within the TSF. Since the wells were designed to totally penetrate the tailings' thickness, additional RCPTu drilling is recommended as the dewatering process advances so that desaturation can be assessed. Typically, the levels in which pore pressure accumulates are associated with lower permeability tailings horizons, below the measured water table in the piezometers, while thicker tailings horizons are desaturated (negligible pore 
North Sector B2 TSF

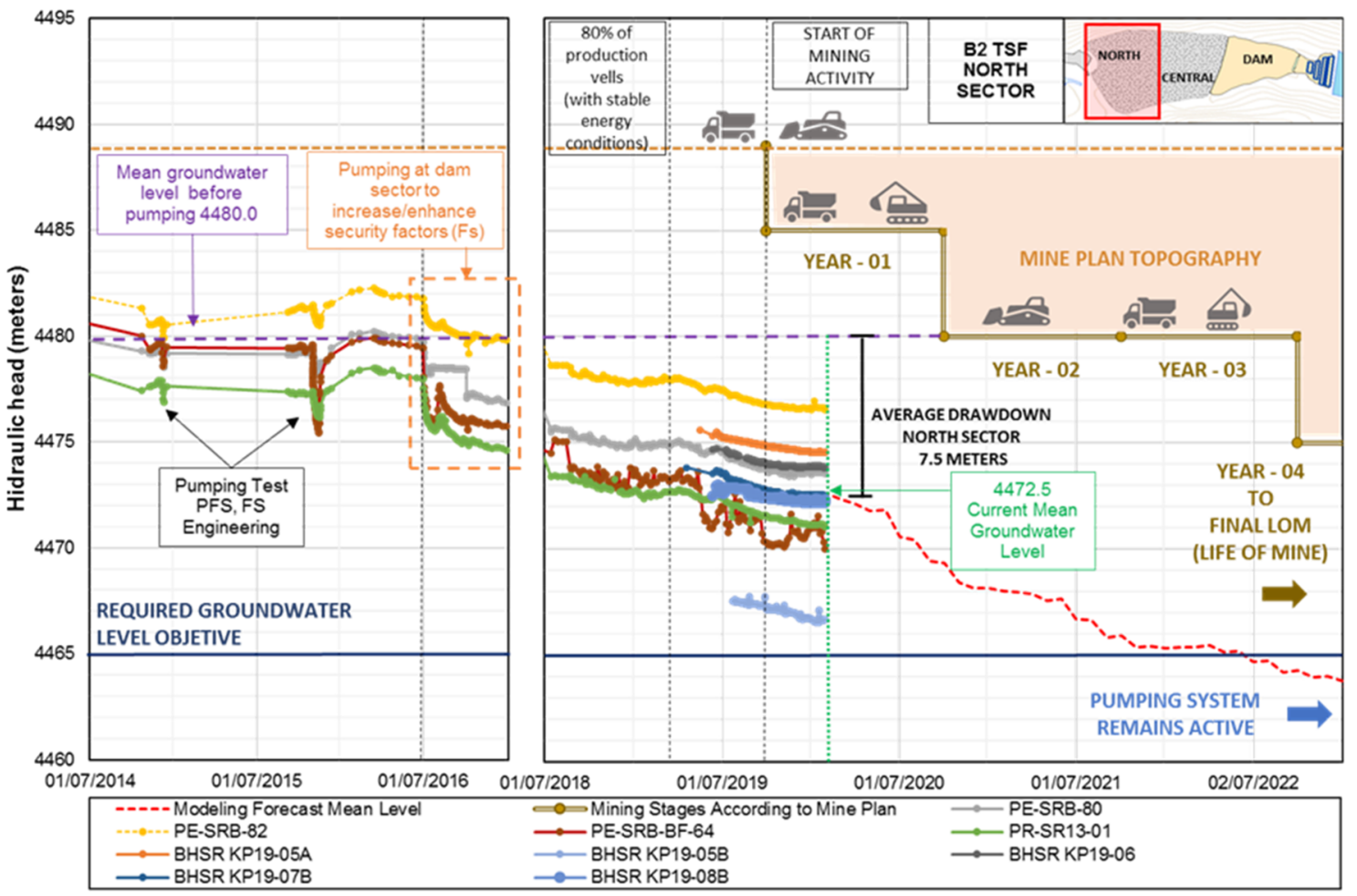

Central Sector B2 TSF

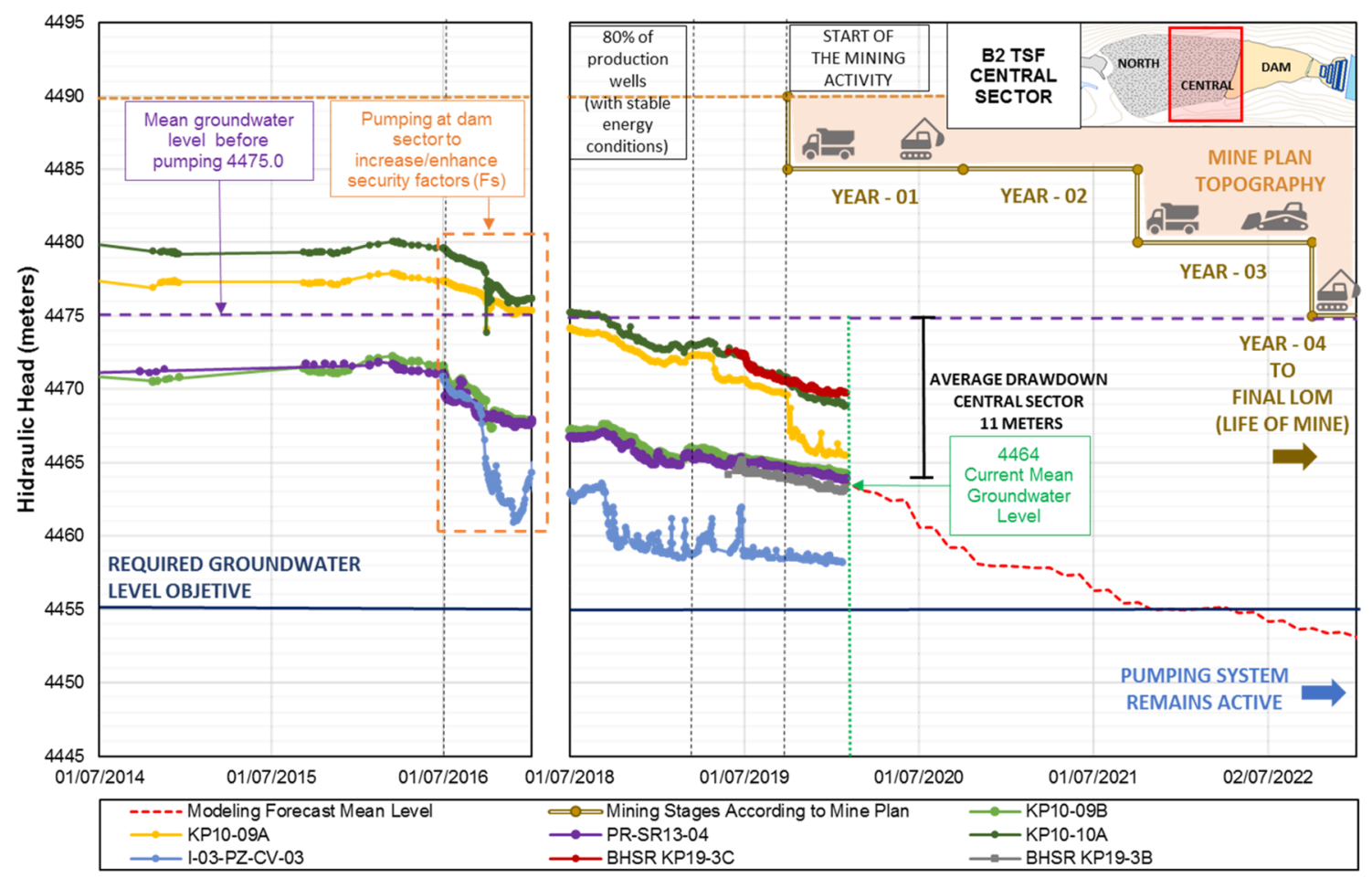

Fig.10 Groundwater piezometric level evolutions for north (up) and central sector (down), including the mine plan topography and expected average forecast modelling predictions 


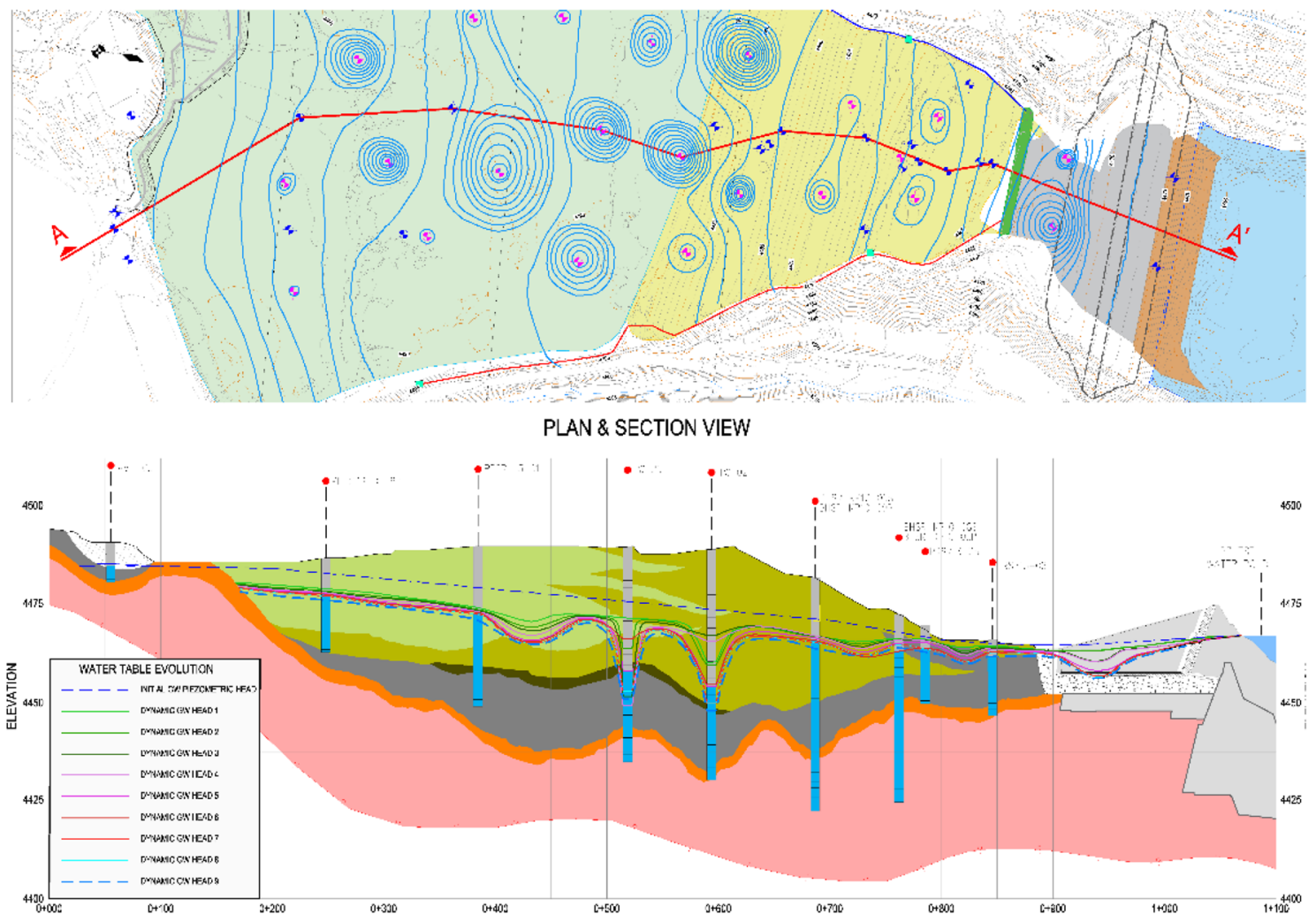

Fig. 11 An example of the evolution of groundwater drawdowns in the main hydrogeological cross-section of the B2 TSF (north-south). Below, each color-line represents a timeline of the water table, inferred and measured at control piezometers

pressures, see Fig. 16). Hydrogeologically, a tailings deposit has a multilayer behaviour.

\section{Updating the Predictive Models}

Finally, accurately forecasting the desaturation of the TSF with automated monitoring of the control network and updating the numerical models are an essential part of anticipating potential problems and challenges. The results can be shown as degree of saturation or moisture content (see Fig. 17).

\section{Conclusions}

This paper illustrates some of the major challenges that can be encountered during the planning and implementation of a TSF dewatering system. Dewatering activities are highly challenging and should be properly planned and integrated into the designing of projects to evaluate the feasibility of reprocessing and recovery of value from old tailings.

Experience has clearly shown that the time required for a dewatering process is a variable that must be considered carefully to avoid critical problems in the project's engineering and the mining plan. Long times are required to appropriately desaturate low permeability materials.

Furthermore, after over a year of operation, some key aspects and difficulties have been identified. Daily performance monitoring, geochemical impacts on equipment and piping, influent water, and in situ humidity (or moisture content) measurements are all aspects that should be considered for similar projects. Numerical modelling simulations based on reliable information regarding unsaturated parameters is essential to define the best dewatering strategy (the no. of wells, time and rates of pumping, etc.), and anticipate operational problems and difficulties. 


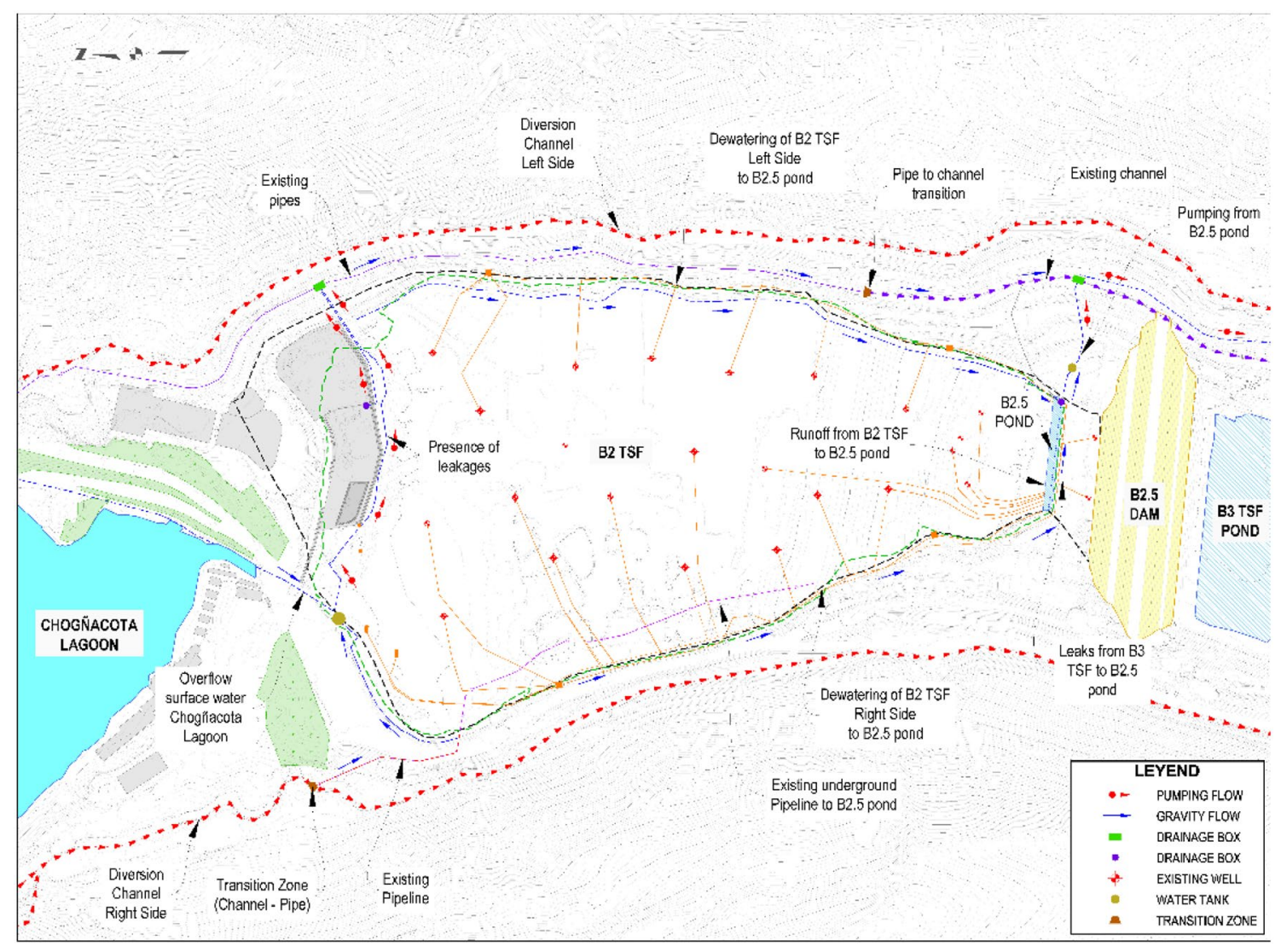

Fig. 12 Surface water management to avoid recharge and water incomes
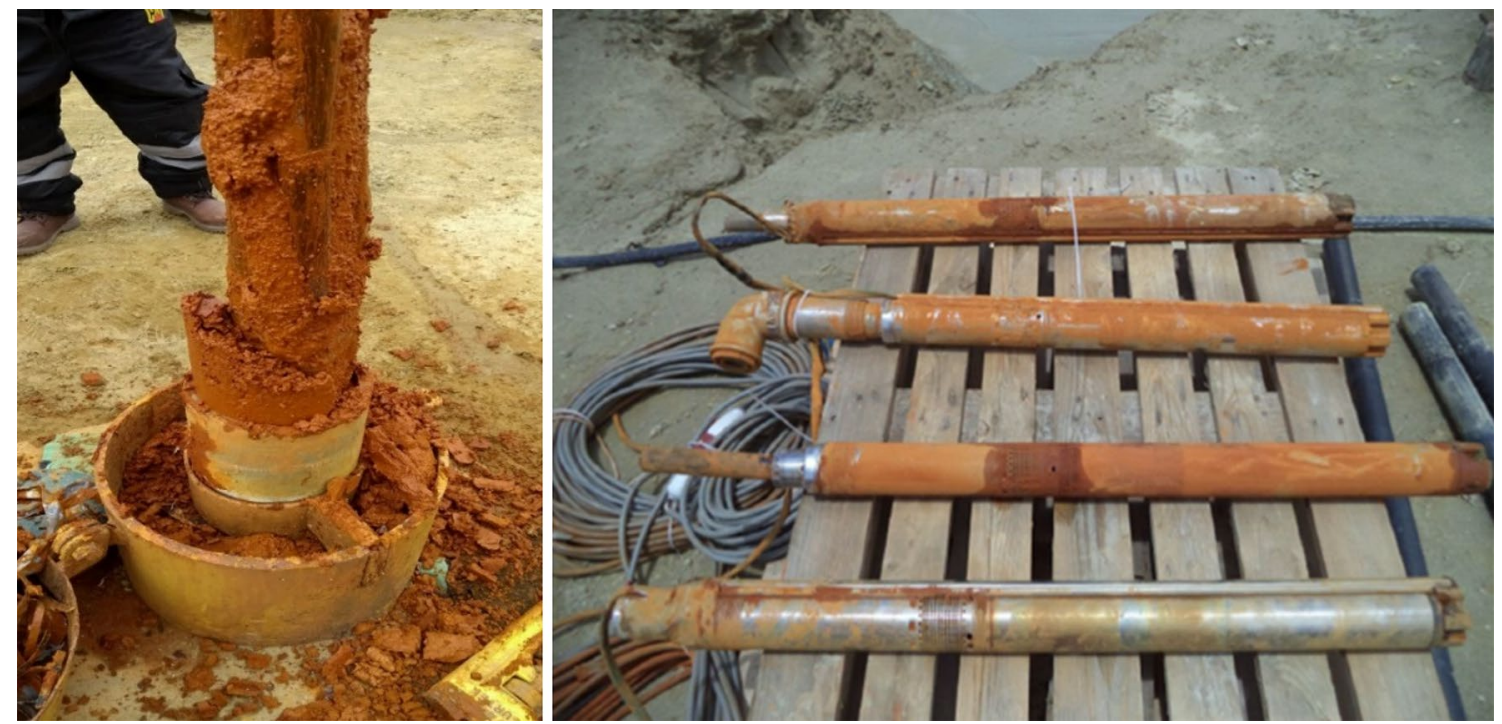

Fig. 13 Examples of accumulation of oxides in pumping equipment (courtesy Julio Larota) 


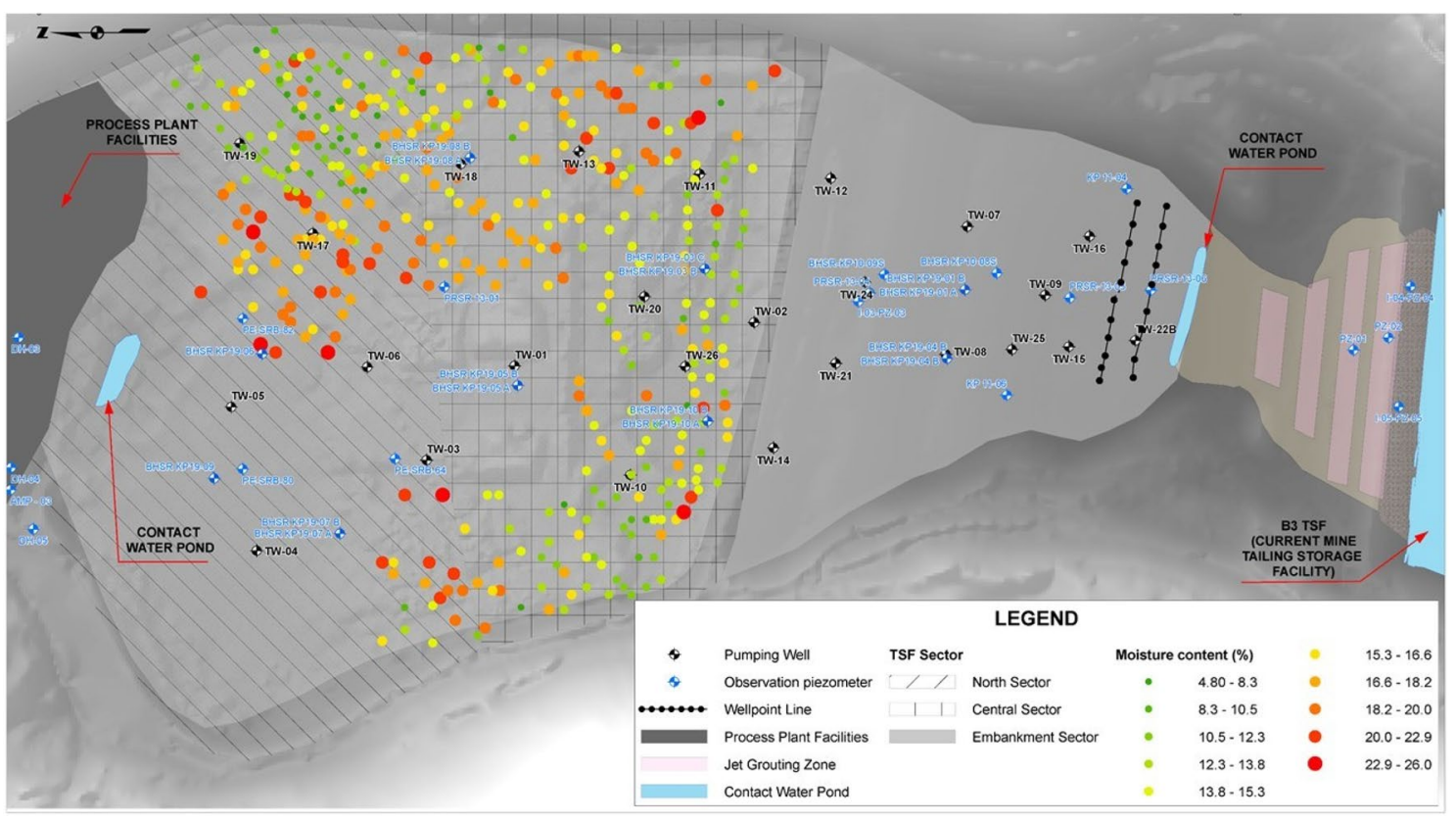

Fig. 14 In situ sampling of water content and humidity during excavation works

Fig. 15 In situ management of stockpiling to ensure adequate humidity

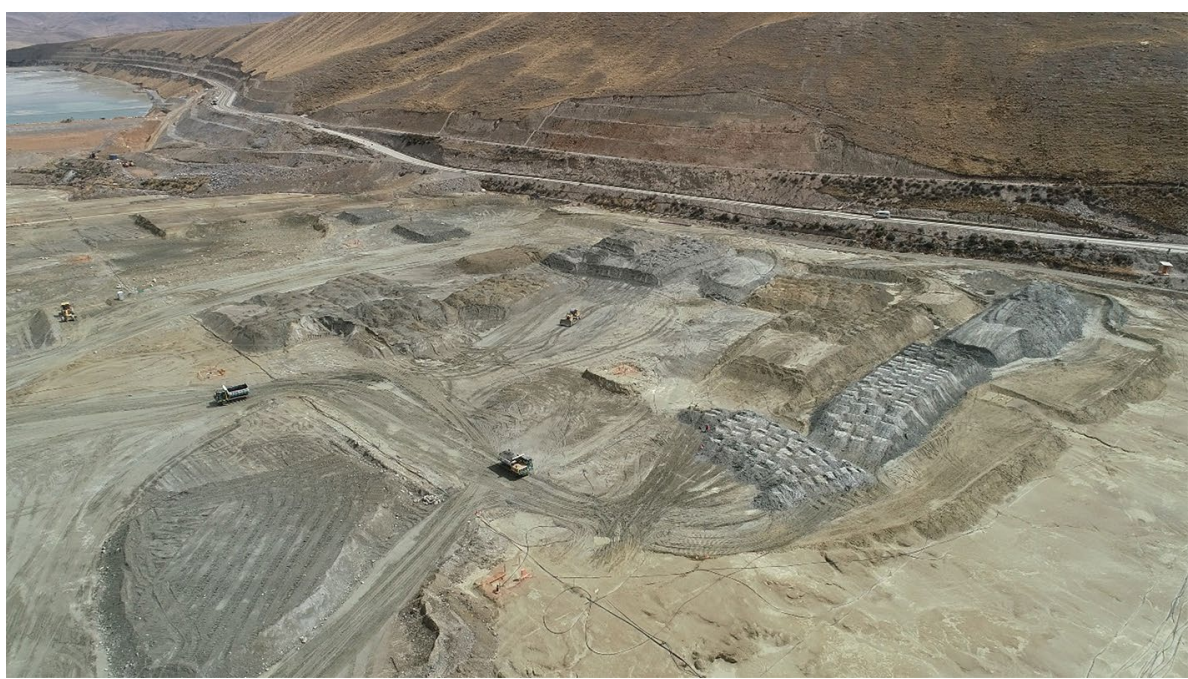




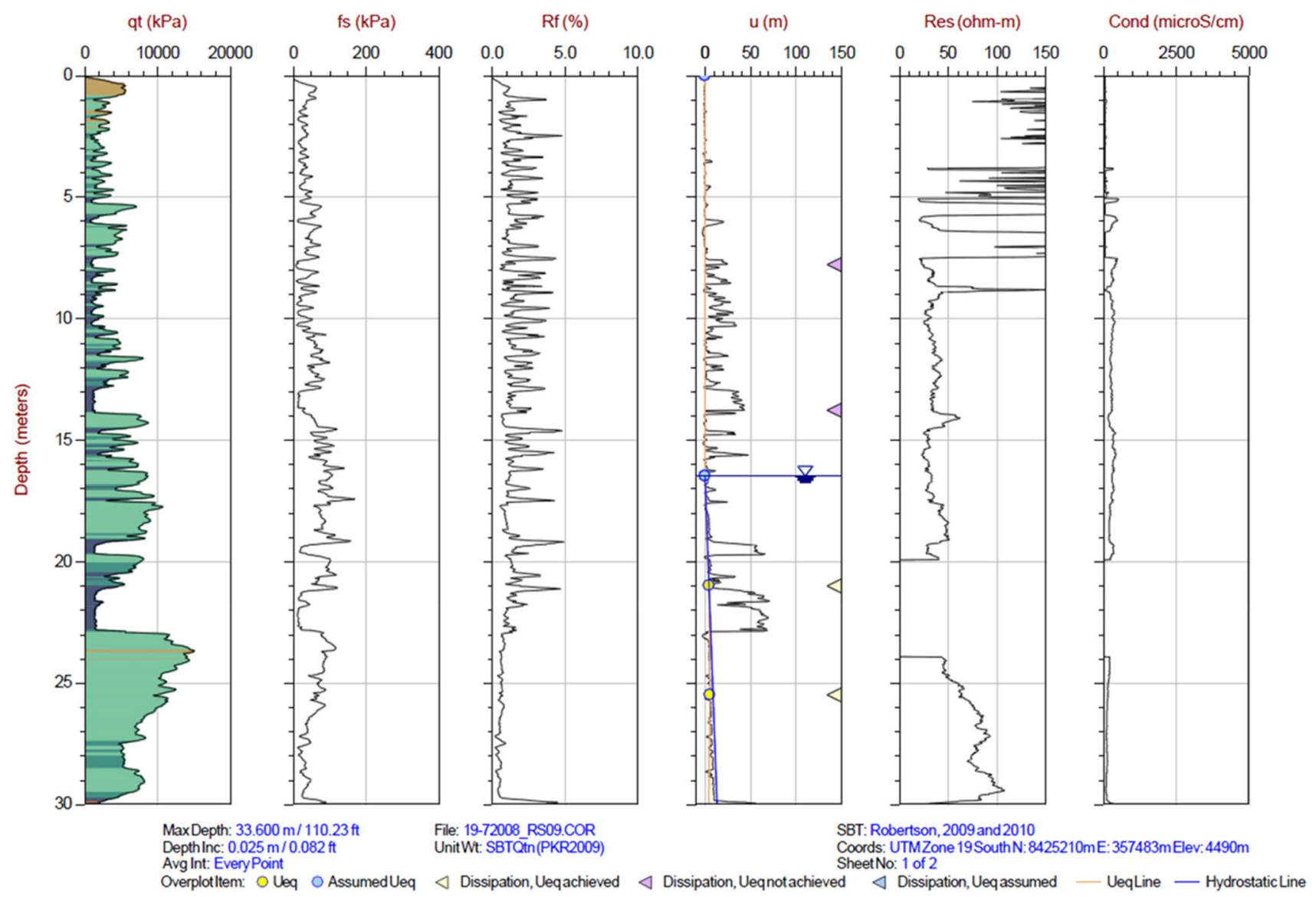

Fig. 16 An example of the resistivity/conductivity cone penetration test (RCPTu or RSCPTu), which combines the downhole measurement of soil resistivity/conductivity and the logging capabilities of the cone penetration test (courtesy of Minsur)

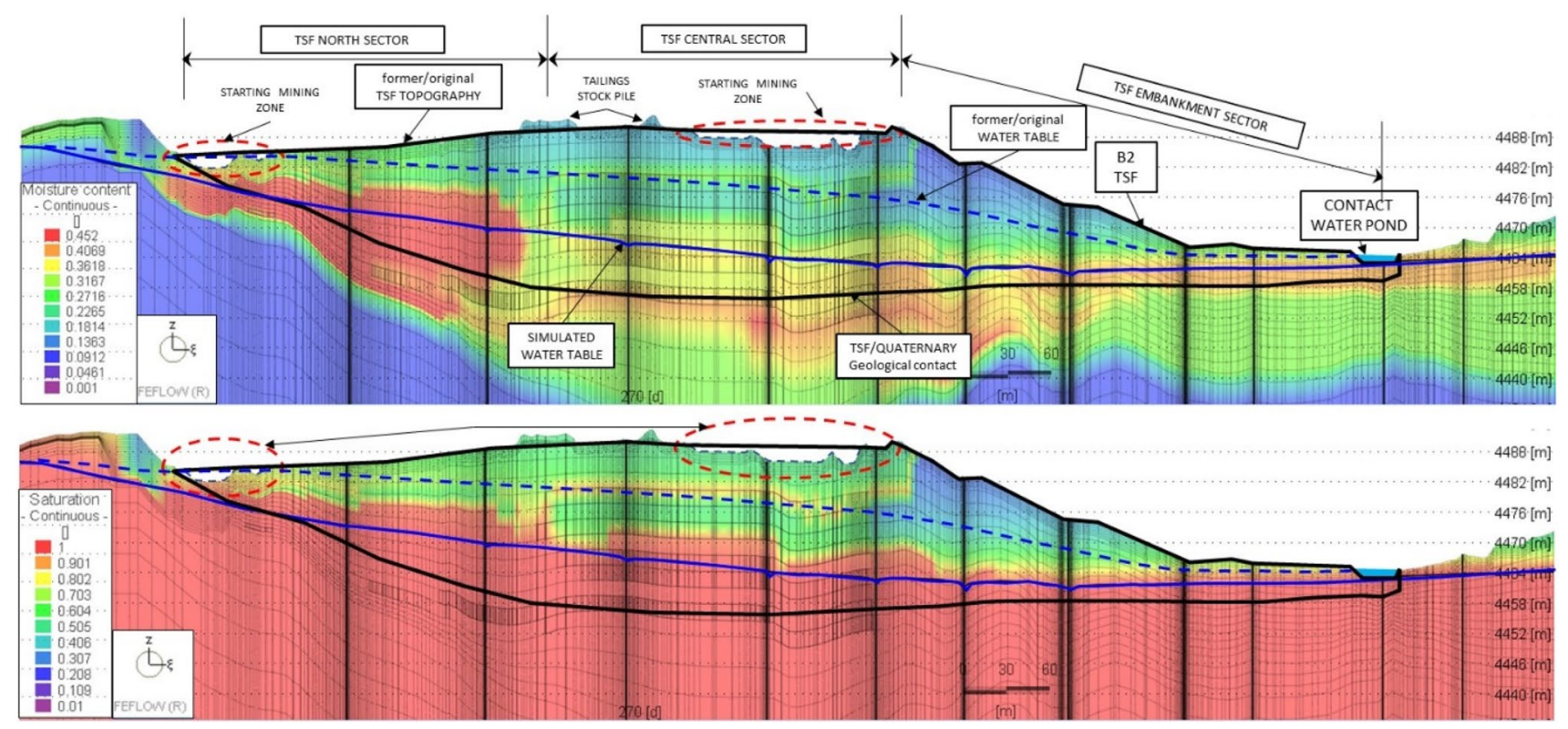

Fig. 17 Forecasted modeling predictions to validate desaturation according to advance in mine plan and security margins in topography (excavated) vs groundwater levels, to ensure that the excavation is done dry. Figure show results on main hydrogeological cross-section of B2 TSF (North-South) 
Acknowledgements Special thanks to the Minsur team for their support and authorization to prepare this publication, both the corporate personnel involved in the project and the outstanding personnel of the San Rafael mine. Both have played an active role in this making this challenge a reality, of which dewatering is a part. The authors also thank all the members of the work team involved in this challenging project, from the drilling companies, laboratories, and equipment suppliers with whom we have optimized techniques, methodologies, and equipment and without whom it would have been difficult to advance even the day to day operation of the project. Special thanks to Prof. Rafael Fernández R. for being a light in which many of us reflect and for the motivation to write this article, also to Dr. Robert Kleinmann for his enormous help and support. Last but not least, the authors appreciate and thank the peer reviewers and the rest of the team of editors, particularly Saranya Sekar, for their meticulous review, helpful suggestions, and overall orientation in this special issue.

Open Access This article is licensed under a Creative Commons Attribution 4.0 International License, which permits use, sharing, adaptation, distribution and reproduction in any medium or format, as long as you give appropriate credit to the original author(s) and the source, provide a link to the Creative Commons licence, and indicate if changes were made. The images or other third party material in this article are included in the article's Creative Commons licence, unless indicated otherwise in a credit line to the material. If material is not included in the article's Creative Commons licence and your intended use is not permitted by statutory regulation or exceeds the permitted use, you will need to obtain permission directly from the copyright holder. To view a copy of this licence, visit http://creativecommons.org/licenses/by/4.0/.

\section{References}

Carlin J (2005) Tin. Mineral commodity summaries. US Geological Survey, Periodic Publication, Reston, pp 174-175

Clark AH, Farrar E, Kontak DJ, Langridge RJ, Arenas Figueroa MJ, France LJ, McBride SL, Woodman PL, Wasteneys HA, Sandeman HA, Archibald DA (1990) Geologic and geochronologic constraints on the metallogenic evolution of the Andes of southeastern Peru. Econ Geol 85:1520-1583

Diersch HJG (2005) FEFLOW. Finite element subsurface flow and transport simulation system. Reference Manual, DHI-WASY $\mathrm{GmbH}$, Berlin, Germany

Eriksson N, Adamek P (2000) The tailings pond failure at the Aznalcóllar mine, Spain. In: Singhal RK, Mehotra AK (eds) Proceedings of environmental issues and management of waste in energy and mineral production, 6th international conference on environmental issues and management of waste in energy and mineral production. Balkema, Rotterdam, pp 109-116

Förstner U (1999) Introduction. In: Azcu JM (ed) Environmental impacts of mining activities: emphasis on mitigation and remedial measures. Springer, Heidelberg, pp 1-3

Fyfe W (1981) The environmental crisis: quantifying geosphere interactions. Science 213(4503):105-110. https://doi. org/10.1126/science.213.4503.105

Huang F, Lyu J, Gao H, Yu Z (2018) Groundwater level distribution in vacuum dewatering method in phreatic aquifers. Geofluids. https://doi.org/10.1155/2018/8459289

HydroSOLVE Inc. (2008) AQTESOLV for windows 95/98/NT/2000/ XP/Vista, version 4.50.004-professional. HydroSOLVE Inc., Reston

Kool JB, Parker JC, Van Genuchten MTH (1987) Parameter estimation for unsaturated flow and transport models-a review. J Hydrol 91:255-293

Kossoff D, Dubbin WE, Alfredsson M, Edwards SJ, Macklin MG, Hudson-Edwards KA (2014) Mine tailings dams: characteristics, failure, environmental impacts, and remediation. Appl Geochem 51:229-245

Lambe TW, Whitman RV (1969) Soil mechanics. Wiley, New York Mlynarczyk M, Sherlock R, Williams-Jones A (2003) San Rafael, Peru: geology and structure of the world's richest tin lode. Miner Deposita 38:555-567. https://doi.org/10.1007/s0012 6-002-0334-z

Olson S, Stark T (2003) Yield strength ratio and liquefaction analysis of slopes and embankments. J Geotech Geoenviron. https://doi. org/10.1061/ASCE1090-02412003129:8727

Papadopulos IS, Cooper HH (1967) Drawdown in a well of large diameter. Water Resour Res 3(1):241-244

Rico M, Benito G, Salgueiro AR, Díez-Herrero A, Pereira HG (2008) Reported tailings dam failures: a review of the European incidents in the worldwide context. J Hazard Mater 152:846-852

Theis CV (1935) The relation between the lowering of the piezometric surface and the rate and duration of discharge of a well using groundwater storage. Am Geophys Union Trans 16:519-524

Youd TL, Idriss IM (2001) Liquefaction resistance of soils: summary report from the 1996 NCEER and 1998 NCEER/ NSF workshops on evaluation of liquefaction resistance of soils. J Geotech Geoenviron. https://doi.org/10.1061/ (ASCE)1090-0241(2001)127:4(297)

Zhai Q, Rahardjo H (2012) Determination of soil-water characteristic curve variables. Comput Geotech 42:37-43 